\title{
Winding Paths: The Road to the Superintendency
}

\author{
Ava J. Muñoz, Ed.D.
}

Dept. of Educational Leadership and Policy Studies, University of Texas Arlington

P.O. Box 19575, Arlington, TX 76019, United States

Tel: 1-817-272-3397 E-mail: avamunoz@uta.edu

Anita M. Pankake, Ed.D.

Dept. of Educational Leadership

The University of Texas Pan American

1201 West University Dr., Edinburg, TX 78539, United States

Tel: 1-956-665-3436_E-mail: apankake@utpa.edu

Marie Simonsson, Ph.D.

Dept. of Educational Leadership

The University of Texas Pan American

1201 West University Dr., Edinburg, TX 78539, United States

Tel: 1-956-665-3436 E-mail: msimonsson@utpa.edu

Shirley J. Mills, Ph.D.

Dept. of Educational Leadership

The University of Texas Pan American

1201 West University Dr., Edinburg, TX 78539, United States

Tel: 1-956-665-3436 E-mail: millssj@utpa.edu

Received: April 24, 2012 Accepted: June 26, 2012 Published: August 1, 2012

doi:10.5296/jse.v2i3.1708

URL: http://dx.doi.org/10.5296/jse.v2i3.1708 


\begin{abstract}
The purpose of this study was to examine the career paths of central office administrators, both males and females. Do males and females experience different career paths? This paper is based on information obtained from a larger study of central office administrators in the state of Texas. Only the data relevant to the topic of career paths will be presented here. The questions addressed in this paper are: 1 . What are the demographics of central office administrators in the state of Texas? 2. What career paths do central office administrators in Texas report? 3. Are there any obvious differences in the career paths of females and male central office administrators?
\end{abstract}

Keywords: Leadership, Gender, Mentoring, Equity, Superintendency 
Women have been promoted to central office administrative positions, in significant numbers, without a problem (Grogan, 1996; Shakeshaft, 1989; Gardiner, Enomoto \& Grogan, 2000). Women are often found in curriculum and instruction departments or personnel departments in numerous districts, but rarely in the position of superintendent (Grogan \& Brunner, 2005). Not so with men. Consequently, having minimal voice in school district decisions occurs when most of the district superintendents are male, there is a perception from the general public that females in the superintendency are an anomaly, when in actuality this conclusion may be but a consequence of a perpetuation of status quo. Unsurprisingly, a patriarchal society does not perceive, and therefore, does not expect women to aspire towards the school superintendency (Blount, 2000, Brunner \& Grogan, 2005, Dana \& Bourisaw, 2006 and Johansen, 2007). Addi-Racah (2006) perceived this inequity when stating, "men are expected to be promoted at school, as this conforms with the dominant male culture and preserves their advantage in society. This pattern of sponsorship may alter, as women in school leadership increases” (p. 297).

In the United States, "although women constitute $75 \%$ of the educational work force and are awarded over half of advanced administrative degrees (Shakeshaft, 1989), less than 10\% of superintendents are female” (Skrla, Scott \& Benestante, 2001, p. 117). A similar situation exists in England (Coleman, 1996). Glass (2000) states that "the two most widely cited reasons for the paucity of women in the superintendency are that women are discouraged from preparing for the superintendency and that school boards will not hire them” (p. 1). Blount (1998) adds that numerous women are locked into tedious, complicated, non-promotional positions that diminish their opportunities for career advancement.

It is this last statement that provides the impetus for this article. The purpose of this study was to examine the career paths of central office administrators, both males and females. Do males and females experience different career paths? This paper is based on information obtained from a larger study of central office administrators in the state of Texas. Only the data relevant to the topic of career paths will be presented here. The questions addressed in this paper are:

1. What are the demographics of central office administrators in the state of Texas?

2. What career paths do central office administrators in Texas report?

3. Are there any obvious differences in the career paths of females and male central office administrators?

What follows is a brief overview of the literature on career paths for executives generally and specially for individuals in education. This will be followed by a description of the methods employed to gather data to address the questions posed. Findings, based on the data collected, will be offered. Conclusions based on the findings and a brief discussion of these conclusions and their implications for district level leadership in Texas will conclude this article.

\section{Literature Review}

For some, a central office position will be a career pinnacle. For others, central office will be an opportunity to gain experiences needed to reach a career goal elsewhere in the organization. 
For some, central office holds neither allure nor necessary opportunities (Pankake \& Muñoz, in press). While a scarcity of literature and research exists regarding the who, what, when, where and how of central office personnel in the educational systems of the United States, according to the National Center for Educational Statistics (May, 1995) over 31,000 positions currently comprise some aspect of central office operations other than the superintendent.

This myriad of positions represents a tremendous investment, i.e., approximately 4 to $5 \%$ of an average school district's budget (Lunenburg \& Ornstein, 2004; Robinson, 1992). Although the total central office administrative and professional staff represents less than 1 percent of all of the staff in the nation's public schools (Forsyth, 2004), many resources (intellectual as well as monetary) are assigned to these positions; information about who occupies them, why they are desirable or not and how individuals move into and out of them is scarce. The position titles, descriptions and reporting lines vary greatly between and among school districts and individual educators, themselves. Also, the type of position may represent a link to other job opportunities or a single opportunity for a central office administrative career. Educators need to know whether a position in central office is a career destination, a barrier or detour, or simply a good place to learn and develop on the way to their ultimate, career goal (Pankake \& Muñoz, in press).

According to Ortiz (1982), central office positions can be categorized and evaluated based on their potential impact on a career. The distance from the governance core of the organization and the groups with which a position has significant contact ("reference groups") influences the probability of acquiring the superintendency. This, in turn, influences whether a position is a rung on the career ladder or a final step. In her book, Career Patterns in Education, Ortiz (1982) admonished women wanting to establish careers to change the cultural expectations for women. From her studies, she reported that the successful women: viewed themselves professionally, had a great deal of experience working with men, and were personally motivated to be successful in professional settings. She also identified the most severe barriers for women as their initial departure from teaching, accepting positions that do not provide for upward mobility, not able to successfully compete with white males for line positions in the organization and traveling "the wrong career path-for example, being a specialist rather than a principal” (Ortiz, 1982, p. 30).

In a study of 142 women, McDrade and Drake (1981), sent questionnaires to 142 women superintendents of public school districts to determine the relationship between career paths of women who successfully arrive at the superintendency and any special problems they encountered along the way. They also sought to determine if there was a relationship between personal, educational, and professional characteristics of women superintendents and career paths. Their final objective was to request advice that these women might have to offer women aspiring to be superintendents. Through a content analysis of questionnaire responses they identified six primary career paths. They also determined that career paths were not discriminated by personal characteristics, professional characteristics, special problems encountered, or advice offered to aspiring women superintendents. However, they did find that career paths were discriminated by educational characteristics, particularly highest degree earned. They concluded, “a career path that requires a woman to specialize may result in less 
classroom experience but does not jeopardize attainment of the superintendency in a small public school district." Special problems encountered by women who become superintendents in small public school districts are pretty much the same no matter the career path followed.

As early as 1975, Estler generated data that demonstrated that almost the same absolute number of female and male teachers hold the credentials to become administrators. The difference to be noted, however, is that the median number of years in teaching before appointment to the elementary principalship is 5 years for males and 15 years for females. Similarly in Paddock's national study (reviewed by Schmuck et al. 1981) the data gathered indicated that women and male administrators generally have similar career paths. However, Paddock concluded that the variations from the male norm-for example, women's later entry age and their career discontinuities, illustrate that career patterns and attitudes reflected the interaction between institutional and individual pressures, but that women were highly satisfied with their positions from both a professional and a personal standpoint.

Caroline Boyce Jackson (1980) examined the career paths of women superintendents in her study that included a national sample. Her findings include the following (Jackson 1980):

- Most of the women reported beginning their administrative careers at either the elementary level of in a central office staff position.

- Most of the positions secured by women cam as a results of "outside influence"

- Little or no conscious career planning was done

- Being geographically mobile was viewed as important by women in administrative position both for themselves and for women aspiring to be in administrative positions.

- No pattern of sex role conflict in the handling of home and career responsibilities was discovered

- The women tried to avoid both formal and informal situations in which they knew they would not be accepted because of their sex.

- The women described successful women school administrators as having sensitivity, good interpersonal relationships, visibility, positivism and optimism, good conflict resolution skills, hard work, high energy level, honesty, and the use of families as a support base.

- Conversely, weaknesses seen as being unique to women in administrative positions were attributed primarily to socialization and cultural expectations

(pp. 179-180).

In 1984, Dopp conducted a study regarding career paths of women school superintendents in Illinois. She investigated the patterns of personal and professional development of 20 of the 21 female superintendents in Illinois at that time. The women's age ranged from 35-55 and the majority held superintendencies in elementary districts with student enrollments under 500 . Interviews produced information related to the career paths of these women. Of particular 
importance were the positions these persons held after the entry level administrative position. The first administrative position of the majority of these women was the elementary principalship, this was generally followed a central office administrative assignment prior to appointment to the superintendency. This was the case for more than two-thirds of these individuals, before being appointed superintendent of schools. Only 10 percent of the women interviewed reported making a conscious decision early in their administrative careers to become superintendents. In Texas, more than half of the women superintendents responding to a regional survey, responded that they "began their educational career in elementary education. Middle school and high school career trajectories were the next two initial career placements for the superintendents’ group” (Muñoz, 2006, p. 106).

Dopp and Sloan (1986) reviewed three studies of women who achieved the superintendency. Recommendations from these women successful in achieving the superintendency, were that they should:

- Gain broad backgrounds in education, including principalships and central office positions.

-Engage in advanced educational degree programs, especially those involving school finance and practical administrative experiences.

•Engage in early career planning.

-Develop personal and professional support systems to aid them in their successful careers.

-Perceive themselves as social change agents on behalf of women and society.

-Possess the ability to communicate and work well with people (the number one asset of successful superintendents).

-Have positive interpersonal skills, excellent conflict resolution skills, and a high energy level.

-Be willing to be geographically mobile. (Dopp \& Sloan, 1986, pp. 125-126)

Similarly, in their study of mentoring, Sherman, Munoz \& Pankake (2008) reported that “. . . prospective women leaders need to be proactive and take charge of their own paths to leadership. . . to be proactive in seeking the experiences that will lead them to this career goal; that may well mean geographic moves, possible separation from family for extended periods of time, an understanding that all family members will be continuously in the spotlight. It is important that such realities be considered in balance with the desire to achieve the top level position in school districts” (p. 244).

While the number of women in leadership preparation programs is increasing, "only a fraction of superintendency positions have been filled by women compared to the greater number of women in central office positions" (Brunner \& Grogan, 2005, p. 4). The path to the superintendency for $50 \%$ of the women is consistent with their male colleagues' career paths, teacher to principal, principal to central office administrator, central office 
administrator to superintendent.

\section{Methods}

The research methodology and design for this study were mixed methods. According to Creswell (2003) utilizing the mixed methods approach allows for the implementation of both quantitative and qualitative research. The research methodology and design for this study were mixed methods. According to Creswell (2003), utilizing the mixed methods approach allows for the implementation of both quantitative and qualitative research. Creswell posits that, "in a mixed methods design format, the researcher brings together approaches that are included in both the quantitative and qualitative formats" (2003, p. 53). Creswell (2003) described "a mixed methods research problem as "one in which a need exists to both understand the relationship among variables in a situation and explore the topic in further depth” (p. 76).

The collection and analysis of both quantitative (survey) and qualitative (one-to-one interview) data allowed the researcher to examine in further detail the survey instrument responses via select interview data. Findings of one method may be reinforced with the findings of a second method, therefore allowing for both quantitative and qualitative instruments to assist in data gathering to address the research problem (Creswell, 2003).

\section{Findings}

Who works at central office?

Of the 2000+ surveys sent, a total of 248 useable instruments were returned. Of these 248 respondents:

- 160 (65\%) were females and 85 (34\%) were males (3 individuals did not respond to this item, but did complete other items on the survey.)

- 213 of the respondents were White, four were African American, 37 were Hispanic and two reported their ethnicity as Native American

- The vast majority 231 (93\%) reported being married; the remaining were either divorced or single.

An item on the survey asked for respondents to share the title of their current administrative position. The original population for the study was central office administrators with the titles of superintendent, assistant or associate superintendent or deputy superintendent. As seen in the table that follows, some "other" titles were reported, but the majority of the respondents fit into one of the original title categories. It is interesting to notice that the most responses came from superintendents, with the next largest group being assistant superintendents. Only two individuals identified themselves as deputy superintendents. 


\begin{tabular}{|l|l|l|l|l|}
\hline Title of Current Position & All & Male & Female & Unidentified \\
\hline Assistant Superintendent & 94 & 41 & 51 & 2 \\
\hline Superintendent & 122 & 100 & 21 & 1 \\
\hline Associate Superintendent & 13 & 9 & 4 & 0 \\
\hline Other Central Office Position & 16 & 9 & 7 & 0 \\
\hline Deputy Superintendent & 2 & 1 & 1 & 0 \\
\hline No response & 1 & 0 & 1 & 0 \\
\hline Total & 248 & 160 & 85 & 3 \\
\hline
\end{tabular}

Respondents were asked to share information about their work experiences. One item asked for the number of years the individual has served in an instructional position. In response:

\begin{tabular}{|l|l|l|l|}
\hline $\begin{array}{l}\text { \# of years in an } \\
\text { instructional } \\
\text { position }\end{array}$ & Total \#/ \% & Males \# /\% & Females \# /\% \\
\hline 1 to 5 years & $63 / 28 \%$ & $46 / 31 \%$ & $17 / 21 \%$ \\
\hline 6 to 9 years & $72 / 31 \%$ & $48 / 32 \%$ & $24 / 30 \%$ \\
\hline 10 to 15 years & $78 / 34 \%$ & $44 / 30 \%$ & $34 / 43 \%$ \\
\hline 16 to 30 years & $16 / 7 \%$ & $11 / 7 \%$ & $5 / 6 \%$ \\
\hline & 229 & $149 / 65 \%$ & $80 / 35 \%$ \\
\hline
\end{tabular}

For the total group, both males and females, the percentages in each experience category from 1 to 5 through $10-15$ years range from 28-34\%. However, for males, $63 \%$ of this group report 9 or fewer years of instructional experience, while $51 \%$ of the females report 9 or fewer years of instructional experience. Thirty-seven percent of males and $49 \%$ of females reported 10 or more years of instructional experience.

The respondents to this survey are an experienced group of administrators. The survey asked for information regarding the number of year experience in educational administration. Response choices ranged from 1-5 years to 26 or more years. The information in the chart that follows demonstrates that the vast majority (85\%) of the respondents reported having more than 10 years of experience in educational administration. For males, $85 \%$ of them reported 10 or more years of experience in educational administration; similarly, $82 \%$ of the female respondents reported 10 years of experience in educational administration. 


\begin{tabular}{|l|r|c|c|c|}
\hline $\begin{array}{c}\text { Total \# of yrs in Educational } \\
\text { Admin. }\end{array}$ & \multicolumn{1}{c|}{ Total } & Males & Females & $\begin{array}{c}\text { Not } \\
\text { identified }\end{array}$ \\
\hline 0 & 1 & 1 & 0 & 0 \\
\hline $1-5$ years & 6 & 5 & 1 & 0 \\
\hline $6-9$ years & 30 & 17 & 13 & 0 \\
\hline $10-15$ years & 89 & 55 & 31 & 3 \\
\hline $16-20$ years & 55 & 35 & 20 & 0 \\
\hline $21-25$ years & 20 & 13 & 7 & 0 \\
\hline 26 or more & 45 & 33 & 12 & 0 \\
\hline No response & 2 & 1 & 1 & 0 \\
\hline Total & 248 & 160 & 85 & 3 \\
\hline
\end{tabular}

One other item that assists in addressing "Who is at central office?" was information on the number of educational administration positions each person has occupied. For the entire group and for each of the gender groups, 3 or 4 positions was selected most often.

\begin{tabular}{|l|l|c|c|c|}
\hline $\begin{array}{l}\text { Number of Educational } \\
\text { Administration Positions Held }\end{array}$ & Total & Males & Females & Unidentified \\
\hline 0 & 1 & 1 & 0 & 0 \\
\hline 1 & 5 & 3 & 2 & 0 \\
\hline 2 & 29 & 17 & 12 & 1 \\
\hline 3 & 63 & 46 & 17 & 0 \\
\hline 4 & 65 & 43 & 22 & 2 \\
\hline 5 & 37 & 21 & 16 & 0 \\
\hline 6 or more & 36 & 26 & 10 & 0 \\
\hline No response & 9 & 3 & 6 & 0 \\
\hline Total & 248 & 160 & 85 & 3 \\
\hline
\end{tabular}

The final item on the survey asked respondents to Please provide additional comments you would like to make regarding your career path to the superintendency. Thirty-five individuals opted to share comments, regarding their own career paths and/or their advice for aspiring administrators, especially those wanting to be superintendents. The next section of includes some of the comments from these respondents as they deal with career paths taken, importance of campus administrative experience and unconventional or atypical career paths.

\section{Career Paths - Taken and Advocated}

The career paths reported by both male and female respondents were generally traditional with movement from the teacher to campus administrator to central office to superintendency or teacher to campus administrator to superintendency. The following comments are typical of the responses to this request for information: 
I have followed a very traditional path $\ldots$ (male respondent)

teacher(3)-vice-principal(2)-principal(10)-executive

director(1)-assistant

superintendent(3)... (male respondent)

It was important for me to be a teacher, assistant principal, principal, assistant superintendent and then superintendent. I can walk a mile in everyone's shoes and it has been helpful in bring about need change. (male respondent).

High School Teacher, High School Assistant Principal, Elementary Assistant Principal, District Bilingual Director, Superintendent . . . (female respondent)

My career path was: elementary teacher, elementary asst principal, junior high assistant principal, elementary principal, special programs director, assistant superintendent, superintendent. My experience provided me the opportunity to understand many different roles. ... (female respondent)

Several of the respondents emphasized the importance of having campus administrative experience as a prerequisite for success in the superintendency. Having campus administrative experience was viewed as important for credibility with campus administrators. The following quotes from both male and female respondents illustrative this point:

I feel that being a classroom teacher for a number of years made me a better campus administrator. As the current Asst. Sup., I still draw upon many campus experiences for my advice to others and much decision-making. (female respondent)

I believe that having served as a classroom teacher for over 13 years and then as a principal for 4 years has been very beneficial and validating for me as a current superintendent. I find that young administrators who have shallow roots in the classroom (1-3 years) have a harder time relating to teachers and teachers are often weary of administrators who have climbed the administrative ladder too quickly. (female respondent)

Central office positions, without strong campus leadership experience, while often helpful in learning the big picture of how a district operates, do not add a lot of credibility to the resume, or to actual practice in working with principals and teachers (street cred, as it were). . . (female respondent)

I think it is important for aspiring superintendents to have experience in the classroom and as campus administrators. In order to make that happen, sometimes they have to be willing to be mobile and go where the jobs are. (male respondent) 
I have followed a very traditional path and personally I respect superintendents more that follow a pathway which involves quality classroom experience and quality instructional leadership at the campus level. (male respondent)

In addition to emphasizing the importance of campus administrative experience, two of the male respondents even advocated administrative experience at the high school level as providing better preparation for the central office positions, particularly the superintendency:

I think having HS principal experience is the most important. Many of the issues you face as a superintendent will be from the high school. Having experience with the HS principal position will better prepare you than the other principal positions. (male respondent)

Superintendents must have been campus principals, especially at the high school. . . (male respondent)

While there were some variations in the career paths reports, one of the most unconventional was described as follows by a female respondent.

... I stepped from the Kindergarten classroom into the superintendency

and have been in my current position for 11 years. I would say the transition from the classroom to the superintendency was very smooth because my husband had provided many opportunities to become involved in and familiar with many of the demands of the position. He continues to mentor his staff members to become administrators.

Another less convention career path was shared by a male respondent. What he describes could easily be labeled as "the fast track":

My father was a math teacher in a junior high school, and retired with 33 years experience. He knew I was going into teaching and coaching, and recommended to me that I get my mid-management certification as soon as I could. I went into a mid management program as soon as

I received my BS. I had 30 hours of graduate work finished before I took a teaching/coaching position. I finished my master's degree in the summer after the first year I taught in the public schools. I finished the mid management certification the summer after my second year of

teaching in public schools. I spent two more years teaching and coaching before I became an assistant principal in a secondary school. I spent three years in that position before I became a principal in a secondary school. I spent twelve years in that position before attaining my first superintendency, and I have spent the last nine years in that position. I have 28 years educational experience, 24 in educational administration.

The previous statement was one of only a few of those made by males that referenced someone else assisting and encouraging the individual to pursue a career path in educational

administration. Such comments were much more common in the responses of females. The following examples demonstrate this: 
I always enjoyed being a teacher and never really saw myself as being an administrator (was pulled kicking and screaming into a math specialist position). At every level, I have learned and grown with the responsibilites and expectations---still unsure at times if the superintendency is my end goal!

I thought I would teach and coach until retirement. I never believed I wanted to go into administration, until my mentor suggested it back in 1997. My mentor left the district we were both in after I began work on my mid-management. Two years later, he hired me as Director of Instruction/Technology in another district he had just been hired in. So, needless to say, becoming a superintendent is not totally out of my career path at this time.

My career path was atypical in that my master's was in Reading and I was preparing myself to teach on the college level...not to become a campus or district administrator. However, that has been a bonus since my preparation included a strong curriculum background.

\section{Conclusions}

Based on the limited information available for analysis in this study, several conclusions can be confirmed and/or claimed:

- The demographics of the respondents in this study appear to confirm the findings of other studies in that women, as a group, teach longer and enter administration later than their male colleagues.

- The career paths of both groups follow a rather traditional path from classroom to campus administration to central office with few exceptions.

- Both males and females emphasized the importance of experience as a campus administrator in providing a successful foundation for central office administration. Advocates noted this as a source of credibility with those being supervised and a basis for understanding district operations.

- More females than males commented that they either were directly encouraged or actually pulled/pushed into administrative careers.

Through their survey responses, all respondents were able to illuminate valuable instances of their experiences and practices, in the superintendency. Regrettably, it was noted, that women continue to lack the much needed resources, such as mentoring and networking skills to augment the numbers of superintendents to equitable proportions. It is by keeping these insights from the field in mind, that we continue to uphold with much urgency, the vital importance that all educators be allowed the opportunity to work in the capacity they are the most qualified for, regardless of gender.

\section{References}

Addi-Racah, A. (2006). Accessing internal leadership positions at school: Testing the similarity-attraction approach regarding gender in three educational systems in Israel. 
Educational

Administration

Quarterly,

42(3),

291-323.

http://dx.doi.org/10.1177/0013161X05284042

Blount, J. M. (2000). Spinsters, bachelors, and other gender transgressors in school employment, 1850 - 1990. Review of Educational Research, 70(1), 83-101.

Brunner, C.C., \& Grogan, M. (2005, November). Motivation theory and attitudes of aspiration: Why do [not] women central office administrators seek the superintendency? Paper presented at the meeting of the University Council for Educational Administration, Nashville, TN. DRAFT

Coleman, M. (1996). Barriers to career progress for women in education: The perceptions of $\begin{array}{llll}\text { female headteachers. } & \text { Educational }\end{array}$ http://dx.doi.org/10.1080/0013188960380305

Dopp, B.K., \& Sloan, C.A. (1986). Career development and succession of women to the superintendency. The Clearing House, 60(3), 120-126.

Dopp, B.K. (1985). Profile of women superintendents in the state of Illinois. Ph.D. dissertation, Northern Illinois University.

Estler, S. E., (1975). Women as leaders in public education. Signs: Journal of Women in Culture and Society, 1(2), 363-87. http://dx.doi.org/10.1086/493227

Forsyth, J. (2004). Are there too many administrators? The School Administrator. http://www.aasa.org/SchoolAdministratorArticle.aspx?id=10206

Glass, T.E. (2000). Where are all the women superintendents? The School Administrator, electronic copy, pp. 1-6.

Grogan, M., \& Brunner, C.C. (2005). Women leading systems. School Administrator, 62(2), 1-4 (electronic copy).

Jackson, C. B. (1980). Career development for women in public school administration. A study of women school superintendents in the United States. Dissertation Abstracts International (No. 8103104).

Johansen, M.S. (2007). The effect of female strategic managers on organizational performance. Public Organizational Review, 7, 269-279. http://dx.doi.org/10.1007/s11115-007-0036-1

McDrade, T., \& Drake, J.M. (1981). Career path models for women superintendents. The Journal of Educational Research, 75(4), 210-217.

Muñoz, A.J. (2006). Woman's natural field: The effects of mentoring on women central office administrators (Doctoral dissertation). University of Texas-Pan American, Edinburg, TX.

National Center for Educational Statistics. (1995, May). Statistics in brief. Washington, DC: U.S. Department of Education, OERI, NCES-95-213. 


\section{Macrothink}

Sherman, W.H., \& Grogan, M. (2003). Superintendents' responses to the achievement gap: An ethical critique. International Journal of Leadership in Education, 6(3), 223-237. http://dx.doi.org/10.1080/1360312032000090073

\section{Copyright Disclaimer}

Copyright reserved by the author(s).

This article is an open-access article distributed under the terms and conditions of the Creative Commons Attribution license (http://creativecommons.org/licenses/by/3.0/). 